Affective Infrastructures and the Political Imagination

\title{
Hannah Knox
}

On the 6th of August 2005, a helicopter carrying Alejandro Toledo, the then President of Peru, touched down on the edge of the newly laid tarmac of the Iquitos-Nauta road. A barrier had been set up at the inauguration site to separate the several-hundred strong crowd from the politicians. Leaning against the barriers, the crowd who had gathered to mark the ceremonial opening of the road provided the noise and excitement required of just such a celebration. Toledo stood on the road side-by-side with Robinson Rivadeneyra - the President of the region where the highway is located - and performed the play of political office with the announcement of a series of new material and infrastructural investments that central government could now reveal were being offered to the region a stadium, a market, medical equipment for the hospital. The crowd clapped. The president smiled and shook hands. Then Toledo returned to his helicopter, which took off, lifting up from the road and away high over the towns of Iquitos and Nauta that the road had been built to connect.

The inauguration marked an endpoint in a struggle that had been played out over the construction of the Iquitos-Nauta road for the preceding seventy years. The small provincial town of Nauta lies approximately $100 \mathrm{~km}$ from the regional capital Iquitos, in the department of Loreto in the North East of Peru. Nauta is located at the confluence of the two rivers - the Marañon and the Ucayali, which figure large in the descriptions that town's residents give of its history. Nauta was settled in the eighteenth century by a Cocama man called Manual Pacaya. The town is usually said to be named after a local style of ceramic pot called a Mauta which is associated with the indigenous Cocama population of the region, but an alternative story exists that it was named after the canoe that Manuel Pacaya was travelling in when he chose to settle on the land which would later become Nauta. As the town grew, it became an emergent trading post, but at a crucial point in this history the river moved its course. A sandbank appeared in front of the town which prevented large ships from docking, and overnight, the hopes and ambitions that the residents of this small port had of becoming connected to emerging global trade networks was rudely cut short. The newer town of Iquitos, located several hours downstream from Nauta became the site of international trade, whilst the small port of Nauta languished, surviving through fishing, small-scale agriculture and participation in local trade networks.

It was against this background that the dream of a road which would re-connect Nauta into the national and international circulation of goods and people emerged. For many years, people talked about the possible route a road might take, and argued that the project was both feasible and necessary for Nauta's future. With these demands seemingly falling on deaf ears, a group of Nauta residents finally decided, in 1961, to take matters into their own hands. With more discursive forms of political engagement apparently failing to register with local or regional officials, the town decided to demonstrate that it was possible to build a road from Nauta to Iquitos and in an audacious material intervention they organised to cut their own route through the forest. 
This paper builds on ethnographic research that was conducted as part of a collaborative research project with Penny Harvey on politics and road construction in Peru. The Iquitos-Nauta road was one of two main ethnographic field sites and our research involved a combination of: interviews with engineers, townspeople, pioneers, members of NGOs, scientists and academics working in the region; participant observation of daily life in Nauta and Iquitos and of different modes of transportation between the two towns; accompanied walking tours of Nauta, and various new settlements along the road; and archival research on the history and development of the Iquitos-Nauta road and the habitation of the route since the 1930s.

Starting from this tale of how an infrastructural intervention allowed a group of townspeople to articulate their claim for proper incorporation in a national economy, this paper considers how an attention to the lived experience of infrastructure projects might advance discussions regarding the relationship between the agency of materials and the political imagination. There has recently been a burgeoning interest in the role that material relations might play in the formation of political life. Dissatisfied with approaches that have approached politics as a primarily discursive realm (e.g. Habermas 1989), a number of political theorists have begun to ask how an attention to material relations might reinvigorate political theory and our understanding of relations between society, the public, the economy and the state. These approaches attempt to draw political analysis away from a focus on political discourse in order to explore the complex interrelationships that exist between political institutions, market flows and, more recently, environmental politics (Coole and Frost 2010) ${ }^{\mathrm{i}}$.

Others working at the intersection of sociology, geography and political theory have similarly called for a (re)turn to an understanding of materialities and their impingements on situated forms of political action (Marres 2008; Braun and Whatmore 2011; Marres and Lezaun 2011). Noortje Marres (2011) for example, argues that contemporary struggles to transform the actions of citizens into more energy efficient forms of behaviour can only be analysed as a form of politics if we allow objects and materials to play an active part in our description of political process as it is currently being played out through mundane and pragmatic forms of action involving things like smart meters, ecological kettles carbon accounting websites and sustainability blogs. Similarly Sarah Whatmore and Catharina Landstrom (2011) have illustrated how even in the more conventionally conceived spaces of democratic politics such as forums and public meetings, environmental politics is opening up opportunities to explore new forms of political decision-making which allow locally situated and materialised forms of knowledge to become articulated in relation to the abstractions of technical expertise. In shifting attention away from politics as a primarily discursive activity, these new materialist re-workings have distanced themselves from conventional political categories in order to focus instead on processes and relations that exceed these descriptive concepts.

New materialist studies of politics come after long running discussions in science and technology studies that have attempted to better acknowledge material agency in social theory. Studies building on feminist technoscience and actor-network theory have long argued that materials have a capacity to act in the world (Barad 2007, Latour 2004) and 
that developing insights into the political possibilities available for acting in the contemporary world requires an attention to these object-agencies. Investigations of such non-human action support the suggestion that if we wish to understand the social practices and political networks that perpetuate systems of commodity circulation, resource exploitation and social inequality we need to expand our repertoire of analysis to include what Latour famously called 'the missing masses' - those objects, materials and things that should be drawn into analysis and understood as allies, and participants in social practices (Latour, 1992). More recently, the veritable fervour around the radical potential of an ontological form of social analysis beyond the domain of science and technology has led to broader interdisciplinary discussions around the idea that the things, forms, and structures of the worlds which people inhabit should be given their due as the grounds for an alternative or transformed social and political life. In my own discipline of anthropology a recent 'ontological turn' has provided a new language for articulating a reformulation of a long-running interest in incommensurability and difference as grounds for the revitalisation of anthropological theory and ways of worldmaking (Viveiros de Castro 1998, Henare et al 2007, Holbraad and Pederson 2014). Those studying science and technology and those developing forms of ontological analysis in other disciplines have found themselves unlikely partners then, in a theoretical attempt to understand ontology as multiple - as a way of recognising the variety of ways of worlding that exist, and that might provide grounds for a reorganisation of the more problematic assemblages we find ourselves living with (Law 2015, Mol 2002, De la Cadena 2010). No longer do we have a material substrate upon which social life proceeds. Now, in this variety of disciplinary spaces, materials themselves are being recognised as specific, relational, agential and, importantly political.

In anthropology, as in other disciplines, the ontological turn has garnered considerable criticism, from those who are still committed to a mode of describing politics which does not sit easily with the material or ontological claims being proposed (Graeber 2014, Martin, 2014, Turner 2009). Part of the criticism lies in the apparent disposal of the terminologies of political analysis in some of the more radical treaties for the need to think in terms of material agencies, ontological alterity, or more than 'a one-world world' (Law 2015). Ontological approaches are criticized for having replaced concepts like power, state, economy, market, neoliberalism, capitalism, or democracy with terms like alliances, networks, assemblages, form, image and perspective (Bessire and Bond 2014). Critics argue, that something important is lost in this move, for those political concepts that are discarded are not just accidental analytical tools but are powerful modes of framing and describing relationships of relative privilege, power, and control with their own ordering effects in the world (Bessire and Bond 2014, Martin 2014). To do away with these terms, it is argued, is also to do away with the conceptual basis that provides the grounds for tackling poverty, inequality, and exploitation. Removing this language thus risks distancing us from the ethical responsibility to understand how these concepts gain their own force outside the walls of academic debate (Fortun 2014).

Whilst a rejoinder between these positions is probably impossible, infrastructure projects like the Iquitos-Nauta road offer a privileged site through which to attempt to forge an analytic clearing space in which to at least bring these different perspectives into a more productive dialogue. For what is fascinating about infrastructural forms like roads is that 
they necessarily bring together both the material politics highlighted by the ontological turn, with what Fortun calls the 'language ideologies' of the politics of state intervention and corporate control (Fortun 2014: 313, Larkin 2013, von Schnitzler 2013, Mitchell 2011). Here then, we have a perfect case through which to explore not only the question of how objects might have the capacity to affect and indeed reframe social processes as the grounds for a new politics, but also the question of the role that objects and materials play in the reproduction of more conventionally framed forms of political power. This paper attempts to trace the way in materials become political in both these senses, by following how the materiality of a road infrastructure came to participate in the experience and reproduction of politics in the Northern Peruvian Amazon.

\section{Traces of the State}

A journey along the roads of Peru, often provides an opportunity to lament the state of the country today. From a distance, the surface of the Iquitos-Nauta road looks impressive. In place of a muddy red track, there is now a smooth grey tarmac strip wending its way through the forest, receding into the distance. Just a year after its completion, I am taken on a tour of the road by local mototaxi drive Andrés, and his wife, Lucía. They express pride in the finished highway, in particular in a bridge that has been built to cross the river Itaya, and the drains that run underneath the road. There is a thrill to being able to drive at speed along the tarmac, a pleasure in being able to visit the city for the evening or a weekend, and a satisfaction in seeing people begin to build their lives along the side of the road. But they also have criticisms. The road near Nauta is condemned for being too curved, the drains that wick away water are barriers to those who wish to access their newly claimed land, and close attention to the road surface also reveals all is not as it seems. Andrés and Lucía point out to me deep cracks running through the tarmac. Later I am shown a video of a television news report where the journalist also points out the crumbling of the tarmac. Both Andrés and the journalist lament what the crumbling road represents - not just a failure of infrastructure, but a failure of Peruvian politics itself.

How is it then, that something as concrete and mundane as a road could index something as abstract and social as Peruvian politics? What was it about this material structure that enables it to bring distant political forces into the heart of people's lives? As we will see in what follows, the lived experiences of this infrastructure was not limited to just these momentary reflections on the idea of politics, but was also capable of energising politics, mobilising bodies, and bringing about future forms of change. This raises the question of how material arrangements can mobilise people to action in ways that not only describe or imagine political formations like the state but also bring them into being.

Understanding just how material infrastructures can have this effect, offers the beginning of an answer to the broader question about the place of materiality in the experience and operations of politics.

The proposition put forward by this paper is threefold. First by taking as our starting point not the entity of the state, nor the practices of politicians or state officials, but rather the material relationships through which politics is sensed in infrastructure projects, I suggest we can extend the notion of language ideologies or political discourse to forge an account of political action that acknowledges how politics is experienced through 
engagements with material substance. Secondly, turning attention away from perspectives that would see the relationship with materials as one of assemblage (Latour 2004) or intra-action (Barad 2007), I suggest that an attention to the embodied, affective relationship that people experience with material forms provides us with a better starting point from which to interrogate the political implications of the material entanglements that engagements with infrastructures entail. An attention to these embodied, affective engagements with infrastructure allows us to unpack something of the unstable or uneven quality of politics, the ways in which things carry latent stories of their entangled pasts, and the manner in which stories are activated and projected forward into forms of pressure, resistance and a calling forth of a response from the powers that be. Lastly I suggest that an attention to the affective qualities of material engagement opens the way to an understanding of material relating that neither overemphasises the ontological power of materials themselves nor simply returns us to a familiar grid of power relationships between the state, the market the public and the corporation. Instead what we find is what I call material diagnostics: a form of questioning, interrogating, tracing, supposing, linking, storytelling and demonstrating, that is formed in the interstices of bodies, histories and materials as they come together in moments of infrastructural affect.

Thinking in terms of material diagnostics is posed as a challenge both to those committed to a radical ontological turn, and critical political economists. Unlike those putting forward ontological arguments, material diagnostics refuses to allow social relations to be reduced to the monad of either a universal substrate, or a singular case of ontological multiplicity (Law and Singleton 2014; Henare et al 2010). Materials have no meaning in and of themselves, but are, as political economists would argue, enacted in relations of power and politics. But the possibilities that exist for making these relationships are not endless and are constrained in part by material properties and it is in this respect that I also pose a challenge to political economists. For when we turn our attention to material diagnostics, remaining attentive to the participation of materials in political engagement requires that analytically the form of power and the shape of politics in material diagnostics remain underdetermined. That is not to say that political concepts like the state cannot be part of what is being diagnosed - indeed this is precisely what I suggest we see happening in the case of the Iquitos-Nauta road. But an attention to material diagnostics rather than 'the state' or 'capitalism' or 'neoliberalism' helps produce a deessentialization of such concepts that forces a reconsideration of our expectations about how the conditions of possibility for change and the blockages or boundaries that dismantle those possibilities persist. In what follows I explore these issues by attending to three moments in the history of the construction of the Iquitos-Nauta road: life before the road; failing infrastructure and experiences of the finished highway.

\section{Affective Histories}

To begin this discussion, I turn first of all to the experience people had of living in the town of Nauta before the Iquitos-Nauta road was built. Nauta is approximately sixty miles upstream of the regional capital Iquitos, and prior to the completion of the road a river trip to Iquitos on a fast boat would take about five hours to complete. This was not the cheapest way to travel, however, and other slower river barges which were more commonly used to take passengers between Nauta and Iquitos would take some twelve 
hours to arrive in the regional capital, whilst returning against the current would take even longer. If Iquitos was the centre to which Nauta residents oriented themselves, Nauta was also a centre for smaller communities that lived on tributaries higher up the river. Nauta was thus both a hub and an outpost for commodity trading up and down the river.

In spite of this river connection however, Nauta residents emphasised their historical sense of isolation, and their awareness of their separation from Iquitos by miles of undulating forest. As Iquitos had expanded in the 1930s and 40s, and railways, cars, and other motorised vehicles had been brought into the regional capital, a sense of frustration had emerged in Nauta at the way in which the forest separated these two towns. In Iquitos the first few kilometers of what was supposed to be a trans-Amazonian railway that would pass through Nauta, opened in the 1930s and then a small section of road was also built in the direction of Nauta, but from the Nauta end the town remained surrounded by vegetation, save for a few footpaths that connected the main town with smaller villages up and down river. An awareness that infrastructures were being constructed elsewhere but not in Nauta had led to a palpable sense of isolation, and abandonment by the authorities. It was this sense of isolation that was stressed when people from Nauta described the collective feeling of passionate desire and 'longing' for a road that they had experienced since that time.

This longing was so strong that eventually in 1961, the then mayor of Nauta agreed to initiate a project to cut a path through the forest. A local man called Jose Domingo Murayari took responsibility for organising and leading the exploratory trip of 1961 to demonstrate the viability of a road between Nauta and Iquitos. He did not find it hard to gather support from fellow residents of the town and brought together a team of nine men including a cook, a porter and several 'trocheros' - men who would be responsible for cutting down the vegetation to make a navigable path through the jungle. Murayari knew the jungle terrain well and was used to moving through the undergrowth. He was well aware of the dangers that they might face on the trip, from hunger, to heat to poisonous snakes, but even he had not banked on how difficult the trip would be or how long it would take. The group set off without any kind of scientific equipment or specialist clothing. Murayari navigated their way through the jungle using his knowledge of the stars, the vegetation and wind patterns. Twenty-one days after leaving Nauta, exhausted but triumphant the group emerged from the forest on the outskirts of the city of Iquitos.

The feat did not go unrecognised. The capacity of this group of men both to read the terrain in order to arrive in Iquitos as planned, and to survive the difficulties of life in the forest by relying on the trees, berries and streams to provide them with shelter, food and water had piqued the interest of local journalists. On arrival in the city, the group were met by an engineer friend called Morana who drove them to a hotel where they were presented to a crowd of waiting hacks eager to hear about their journey and what they had found along the way in terms of marketable products or land suitable for cultivation.

The trip seemed to have done what was intended. The appearance of these nine bodies emerging dramatically from twenty-one days in the jungle worked to draw forth a response from the authorities. The journalists wrote up their stories. The mayor of Nauta said that he would give a reward to the nine men for their service to the town. And, most 
significantly, perhaps, the national government agreed to send a topographer to Nauta to repeat the trip in order to investigate the technical possibility for the building of the much-desired road across the terrain that the nine men had covered.

$* * *$

Our second moment of material politics brings us forward to 2001. By now the road construction process had been through a series of stops and starts and at this point the road building project was in a state of impasse. In 2001 approximately half the road had been paved, but the rest of the route remained impassable except by foot, and even travel by foot was difficult due to the frequently wet conditions which turned the mud into an impassable sticky mire. This sense of stasis, of being stuck with nowhere to go was compounded by rumours that the money that had been allocated for the construction of the road had been embezzled by politicians and the owners of the companies that had been contracted to construct the highway.

Tired and frustrated at the continued failure of both regional and national governmental bodies to bring this road project to fruition, the people of Nauta had begun to talk again about taking matters into their own hands. This time they did not expect that they could physically advance the construction of the road by building it themselves, but rather hoped that a collective and very visible protest might be able to ignite a reaction that would trigger the project to start moving again. Eventually the frustration was brought to a head when a large group of Nauta residents decided that they would walk the length of the route of the road from Nauta to the Consejo Transitorio de Administracion Regional de Loreto (CTAR) ${ }^{\mathrm{ii}}$ offices on the outskirts of Iquitos and would demand that the road project be restarted.

Once again the journey was difficult, involving a twenty-four hour walk on muddy and uneven ground. When they arrived at the CTAR offices the crowd were tired but eager to make themselves heard to the officials inside. Standing outside they requested to speak to the head of the regional government and when no one appeared their demands became louder and more vociferous. They began to shout and chant that they would burn down the regional government offices if they were not listened to. Inside, the officials felt that they protesters had them under siege. They were nervous about what the protestors were threatening to do, and so hasty phone calls were made to Lima to see if a deal could be done that would calm the protestors. Remarkably, the protest was enough to push the Ministry of Transport to agree that the road construction would be restarted, this time with CTAR at the helm.

$* * *$

The final example of material politics brings us up to the present and to the reaction that people had to the completed highway. In 2005 the road was finally finished and the inauguration ceremony with which this chapter opened was held. There was great hope for the road: as one interviewee put it, 'We had the dream that when they finished the Nauta road the town would grow, it would bring in investment, we would have hotels, restaurants, and tourist attractions for visitors to come and see the headwaters of the Amazon'. Many were amazed that what was locally known as 'the most expensive road 
in the world' had ever come to fruition and there was a great deal of enthusiasm when it first opened. People took taxi rides up and down the route and even when I arrived in Iquitos several months after the road had been completed, experience of travel on the new road would evoke excited telling of the story of how Nauta's residents were instrumental in bringing this highway into being. Speeding along the road, there was a clear pride in the work that the people of Nauta had done to make the highway a reality.

At the same time, the weight of the promises that had being built into this road construction project quickly began to bear down on the initial excitement of the completed highway. Just as Lucía and Andrés lamented the crumbling tarmac and the state of Peruvian politics to which this pointed, so too did others decry the lost opportunities, the lack of investment, the absence of tourists and the failure of the road to bring economic benefits to Nauta. The interviewee quoted above, qualified his hopes for the road by pointing out that what had actually materialised was that 'tourists come here on a package tour, they buy their package abroad, come, walk, make a tour and then go back not having spend a dime, not even having bought a bottle of mineral water'. The influx of tourists that had been hoped for had never materialised.

This question of why the road did not seem to be fulfilling its promises was frequently reworked to become a question about who the road was really for. One of the people that we met during our research was an investigative journalist who was trying to unpack just this question of who the road was really for, through a detailed investigation into several corruption cases that were being pursued through the courts. This journalist had been centrally involved in incarcerating the main protagonists of a scandal in which politicians and contractors, entangled not only by contractual agreements but also by family ties, had embezzled money and left the Iquitos-Nauta road project languishing. Driven by both the stops and starts in construction over the years, the continued cracks in the tarmac and the presence of rusting heaps of impounded equipment and materials in a camp alongside the present road, the journalist had made it his mission to find documentation that would allow him to trace and uncover the contracts, the meetings, the people and the agreements that had culminated in the current situation of infrastructural failure, tracing precisely who the road had benefitted and why it continued to fail the local population.

For this investigative journalist, it was far from clear precisely who had benefitted personally from the road, for were it so, his job of investigation would not have been necessary. This slippery set of relations that he was attempting to trace by using a highlighter pen to pick out names in official documentation and creating a story of links between traces of nefarious activity was simultaneously intangible, opaque and potentially traceable. In the act of tracing these relations he, like Andrés and Lucía, found himself unravelling not only the circulation of money, materials and relationships, but the workings of Peruvian politics itself.

\section{Infrastructural Politics}

How, then do these three moments of infrastructural politics help shed light on the relationship between materials and political imagination? As an infrastructure, it might be argued that the Iquitos-Nauta road must by its very nature be considered a political project. Infrastructures are so deeply defined as projects of national improvement that 
nowadays the link between road and state politics seems almost self evident (Dalakoglou and Harvey 2012, Guldi 2012). Infrastructures are the backbone of modern nation states and projects of such scale and proportion necessarily require the involvement of national and regional governments both for their funding and their implementation (Harvey and Knox 2015, Amin 2013, 2014). Nonetheless to solely point out that infrastructures are funded by or organised by state or political authorities does not tell us much about the varieties of political engagement that infrastructure projects like this produce and the way in which political engagement might be tied to the specifics of the material environments they engage.

Recent work on the social importance of both contemporary and historical infrastructures has highlighted the many ways in which infrastructural forms might be understood to interplay with politics. Moving beyond a literal reading of the role of political institutions in bringing infrastructure projects into being, several scholars have opened up the study of infrastructural politics to include an attention to the promises (Larkin 2013, Amin 2014), pressures (Anand, 2011), imaginaries (Harvey and Knox), ideologies (Humphrey 2005), and temporalities (Hetherington 2014) that infrastructural politics entails (see also Andrew Barry 2013). Infrastructures are highlighted for the way in which they provide both the material foundations for social life and the imaginative resources through which political participation is structured. Anand (2011), for example demonstrates how struggles over a water pipeline in Mumbai, entailed an alignment between the dynamics of political pressure and water pressure. Bringing material properties and social ambitions into the same analysis, Anand demonstrates how material politics operates through what he calls, following Gandy (2008:125) 'microspheres of negotiation' where what is being negotiated is both the shape of material infrastructure and the form of social relations (Anand 2011:544).

There are parallels here with what was experienced in the case of the Iquitos-Nauta road. The march on the regional government was an attempt to bring about a change in material infrastructure that would also bring about a change in the status of social and political relations. The Nauta residents who went on the march hoped that the appearance of a road would simultaneously evidence the state in their lives, repairing in the process the pervasive sense of exclusion and abandonment that people in Nauta had been struggling with for many years. At the same time, the language of 'negotiation' risks missing an important dimension of the experiences that Nauta residents had of life both before and after the construction of the road. For, in each of the stages of the road's construction, the process of engagement or negotiation with authorities appeared to be preceded by an experiential relationship with the material environment within which people were living that was central to the fermentation of political action.

Take the case of the initial project to make a cut through the forest. The need for this cut was tied to highly evocative accounts of what it was like to live surrounded by forests that were impossible for most people to navigate. The sense of longing for a road connection and the associated feeling of disconnection and abandonment was situated as an effect of both the experience of living penned in by the thick forest that surrounded the town, the geography of the river connections that had defined the social status of the 
town, and an awareness of the new possibilities that might be opened up by emerging infrastructural forms.

In the second case of the march on the regional government, the description of the collective march was preceded by an explanation of the frustration of being stuck in a process that should be moving. The difficulty of walking in sticky mud was a fitting allegory for a description of the difficulty of moving forward a road construction project that suffered from inherent inertia - embodied in piles of rotting road construction materials, abandoned and rusting vehicles and a seemingly never-ending lack of progress. And finally, in the third example, even when the road was finished, the materiality of the road itself - whether its smooth tarmac, its crumbling surface, or its capacity to ferry tourists into the town, was central to descriptions that people gave of their dreams of what the future may or may not bring. What the stories of the Iquitos-Nauta road pointed to then, was the way in which material conditions were enfolded into the flow of life, and where their meaning or significance was intensified at particular times, drawing a response from which a 'micropolitics of negotiation' (Anand, 2011), a counterpolitics or accession to other interests might proceed.

The embodied and engaged dimension of social and political experience, has been effectively evoked by other political anthropologists who have pursued affective approaches to understanding the state (Aretxaga 2003, Stoler, 2004, Reeves 2013, Navaro Yashin 2003, Taussig 1997). Yael Navaro-Yashin's haunting description of the life of Turkish Cypriot families living in an unresolved limbo in the abandoned homes of former Greek residents in Northern Cyprus, demonstrates powerfully the affective hold that material structures can have and the capacity of this affective hold to shape an experience of politics. Madeleine Reeves' work on situated border-making practices at the boundary of Kyrgyzstan and Uzbekistan similarly evokes the affective power of the line that cannot be crossed, illustrating how politics 'becomes passionate, morphing from homes and tea houses onto the street' (Reeves, 2011:921). Politics in both these pieces is neither prior to nor determined by material structures, but emerges and is reworked through affective engagements with the material arrangements of the worlds in which people live.

Affect is thus a potentially productive concept in our consideration of the relationship between materiality and politics, for it provides a language to point to the concatenation of forces that ebb and flow and manifest in and between bodies, offering a more emergent and temporally uneven sense of how meaning is related to embodied material interaction that the conventional political language of 'negotiation'. Seigworth and Gregg describe affect as:

"a supple incrementalism of ever-modulating force-relations - that rises and falls not only along various rhythms and modalities of encounter but also through the troughs and sieves of sensation and sensibility, an incrementalism that coincides with comportments of matter of virtually any and every sort" (Gregg and Seigworth 2010: 2).

Affect thus describes an important dimension of the experience of living and engaging with the materiality of environments, but it does not explain how these embodied relationships become related to politics. For this I turn to one of the key characteristics of 
infrastructure: its tendency to be treated as unremarkable and its capacity to emerge out of this state of normality into a state of exception.

\section{Infrastructural Rupture}

One of the most frequently observed truisms about infrastructures in the social science literatures is, as Star and Ruhleder presciently observed some 20 years ago, that infrastructures are characterised by only being 'visible upon breakdown' (Star and Ruhleder 1996). Most of the time infrastructures are characterised by their invisibility or at least the lack of attention that is paid to them as people go about their business, drive their cars, visit their families, or pay their taxes. What is perhaps most interesting about this observation for our purposes is that the normal state of infrastructure is deemed to be the state when it is unremarkable. The moment that it becomes remarkable - either because it breaks down or, I would add, because it comes to perform a kind of infrastructural ‘sublime' (Nye 1996 (also see Robbins 2002) - is the moment where politics enters the frame.

Star and Ruhleder (1996) suggest that this occurs primarily in those moments when infrastructural forms fail - that is when they fail to function in the terms within which they were designed. Failure is of course relative to the expectations and understandings of what is understood to be the normal operation or functioning of such material relations (Douglas 1966). In the case of the experiences of Nauta residents prior to the construction of the road, the forest became an enclosing barrier only when the possibilities of terrestrial connectivity were realised in Iquitos. Similarly the failure of the road to be completed was relative to the contracts, agreements and plans that provided timelines and expectations about when it would be built.

Recognising that failure is not a feature of materials themselves but an experience that is determined by expectations about the appropriate functioning of materials, allows us to begin to understand how material relations might be participating in the production of political modes of engagement. As with Navaro-Yashin's (2003) study that focused on the experience of historical rupture and Reeves' (2013) account that saw the border as a space of discontinuity, so too infrastructural or material failures produce their own kind of rupture. It is this break or disjuncture that I suggest creates the conditions for an embodied or affective response. An embodied or affective relationship with road infrastructure then, is the surprise that comes from the jolt as the bus passes over a pot hole, the frustration of the roadblock that prevents the normal flow of movement along a road, the feeling of freedom or alternatively fear, when a vehicle accelerates fast along a stretch of highway and that crushing disappointment of the crumbling roadway whose very ontological stability seems to be being blown away in the wind.

Focusing on infrastructural rupture rather than infrastructural failure also allows us to extend Star and Ruhleder's (1996) understanding of infrastructural relations beyond a politics of breakdown to incorporate more positive forms of existential rupture brought about by infrastructural form. Moments of material or infrastructural rupture do not have to simply be restricted to those times when infrastructures fail but might equally be a response to when they succeed particularly well. Engineers I spoke to who were visiting the Iquitos-Nauta road construction project talked with enthusiasm about engineering 
feats in other parts of the world, describing the majesty of the Millau bridge in France or the engineering prowess demonstrated by the Channel Tunnel that runs under the sea between the UK and France. These feats of engineering were evoked as examples of what was technically feasible but politically impossible in a country like Peru and their aweinspiring descriptions of these structures was tied to a lament at the corruption that they saw as the cause of the substandard Peruvian roads with their tortuous curves, their indirect routings and their poor quality materials.

\section{Material Diagnostics}

Isabelle Stengers (2010) has written powerfully of the way in which material relations are central to the project of discovery. Her work attempts to rethink the history of scientific knowledge by decentring the place of human intellectual work from the process of scientific discovery and recovering the active part that materials have played in the production both of knowledge and of the world to which that knowledge refers. Stengers explores this relationship by talking of the way in which materials participate in processes which 'force thinking', arguing that "when "thinking" is related to a cause that forces thinking and feeling, it is not to be characterized in general terms, as a human production' (Stengers 2011: 17). In a similar manner, I suggest that the affective moment of rupture on the Iquitos-Nauta road likewise had the capacity to force thought. Here, affective engagements with material environments did the work of generating a response by producing an opening or a gap from which questions and answers arose.

Thus it was that the feeling of abandonment was greeted with the question of what should we do, who should do it, how should we make it happen? Similarly the frustration at the stoppages in the construction process prompted discussions of why the road was not being built and what kinds of pressure or intervention might make it start up again. Even when the road was finished, curves which slowed down the speed of travel prompted questions about why the road had been designed in this way, what deals must have been done to decide upon the routing, and what this told people about the kind of political and material object the road really was. Prompted by ongoing disrepair, missing money and impounded materials, many continue to ask who the road is really for, and wonder how they might channel its potential benefits toward themselves and their town.

The relationship between the material environment and the political imagination that I have traced in this paper, was thus not primarily representational or indexical. The road and the land did not simply 'stand for' the state or the community, nor index the state's involvement in its construction. Neither were the materials that we have encountered in this paper, straightforwardly incorporated into prior ways of doing or interpreting politics. Rather the affective engagement with material environments that characterised people's experiences of the Iquitos-Nauta road project, had the effect of producing a rupture or gap between expectation and actuality that opened up the space for what I term 'material diagnostics'.

This diagnostic space produced in the rupture between the expected and the unexpected constituted politics not as a closed set of relationships that could be mapped and counted, but rather as a multiplicity of voices, both potential and actual. On the road, as questions were asked at each stage about the reasons for isolation, for stagnation and for failure, 
different people and organisations were called upon, and came to give their responses. Environmentalists jostled with small-scale entrepreneurs, engineers provided accounts which competed with those of local residents, and calls were made for government officials and company executives to provide their own descriptions of their role in the road construction process. Affective material engagements provided an impetus that initiated discussions out of which people come to forge multiple, competing and imagined accounts of the forces, relations, institutions and entities out of which the current situation came to be and from which a different future might be made.

Finally it is crucial to recognise that this material diagnostics was not just discursive, but was itself the basis of future projects of material transformation. It was out of this kind of material diagnostic that the initial act of making a cut through the forest had come into being and the act of marching on the government was decided upon. In both of these instances, the issues and questions of the relative responsibility of local populations, local authorities and the national government were formed, enacted and brought into being. Thus, although what materialised in each of these encounters was not, as some of the more radical ontologists might hope, a fundamentally different or other mode of seeing the world, neither was the world unchanged. Those very familiar political entities with which people were attempting to engage - the state, the nation, the community - were themselves refigured - both materially and imaginatively - through the process through which they were called to account for themselves. When the protestors marched on the local government they were not just reproducing an imagined idea of the state as an agent in a political terrain, but were also demanding that a set of relations actualise itself as 'the state' by bringing their road into being. We might go so far as to say that the march itself then produced its own affective moment, rupturing the normal work of government officials and causing them to formulate a response to the protestors and to restart the project of construction. Just as protestors remade the state, so the state remade society, continuing an on-going play of material affect and diagnostic response.

\section{Conclusion}

I return, in conclusion, to the inauguration. It was telling for many who had fought for this road that the president flew in a helicopter, not going to either of the places that the road connected. The president was the embodiment of the institutions, agencies, and forces that people had been working to materialise in their mundane and affective engagements with infrastructure, but when he arrived his visit was fleeting, and his presence strikingly ephemeral. Scholars of the state have long pointed out the folly of attempting to describe political relationships by focusing on political institutions and the relationship with those they serve as if the institutions and their publics were fully formed in advance of their interactions, and moreover delimit the site where politics is located (Sharma and Gupta 2006, Mitchell 2006).

Here, in the visit of the head of state, politics seemed, if anything, more distant than ever. The surviving pioneers who had made the first cut through the forest had had great hope that the inauguration would finally see the gap between the mundane politics of infrastructural engagements and the politics of the state finally bridged. But it was not to be. Whilst the president was stood promising new material structures for the people of Nauta, the pioneers were sat outside the town hall waiting for a lift to the inauguration 
site. They had hoped that this would be the day they would be recognised for the work that they had done, that they would finally receive a small monthly pension to thank them for their service to the town. However, their lift never turned up. They never got to make their claim for compensation and now the president had left, the road remaining the only sign of all of their efforts and work over the years.

In writing this account of material politics I have followed in the footsteps of those who argue for an openness to seeing and describing ontological relationships that cannot be described by conventional forms of political analysis. One of the reasons for much of the enthusiasm for approaches that attend to ontological politics - whether they focus on the agency of materials, or look to non-western ways of world-making - is that an attention to material properties seems to offer a means to expand the relational possibilities available for imagining what politics might look like. Just as new technologies have been claimed to herald new political possibilities (Haraway 1991), and encounters with nonwestern 'others' have provided the basis for a reinvigoration of western social theory (Viveiros de Castro 1998), so too, an attention to relations with non-human forces and materialities seems to offer another realm through which we can rethink what kind of politics might be possible. There is a hope that by attending to the relational dynamics of human/non-human entities as they occur in a whole range of different circumstances and settings, we might find grounds for an alternative way of thinking, being and organising ourselves.

At the same time, the pathos and familiarity of people's experiences of infrastructural politics on the Iquitos-Nauta road highlights the importance of not blinding ourselves to the limits of material transformation, and the recursive quality of the diagnostic processes in which concepts like the state, corporation, responsibility, and ownership are remade as important dimensions of the landscapes in which people find themselves. This is not an argument that we need to start from a position where the contours of politics are known and the players already assigned. Rather it is a call to be attentive to the way in which diagnostic processes that are prompted by material affects then require the mobilisation of both material and conceptual resources to forge an appropriate response (Stengers 2010). In an attention to affective infrastructure, we thus discover that politics is not a concrete set of either existing or future relationships that can be described or prescribed, but is rather a potential towards which people move in the process of material engagement.

In Nauta, there is now a statue of the first pioneer. Recently repainted gold, the statue is supposed to stand as a reminder for the work that these nine men did to bring this road into being. However when the statue was unveiled there were some people in the town who were upset. They felt that the face of the pioneer did not look like the man who struggled his way through the forest to Iquitos, but instead bore an uncanny resemblance to Nauta's mayor. In The Magic of the State, Michael Taussig (1997) talks about a statue of 'The Liberator'. He sees the fixing of the figure of the liberator into a heroic statue form as a kind of forgetting. For Taussig, forgetting is central to the apparition of the state and its capacity to appear a powerful political agent. Whilst the face of the mayor shining out at the residents of Nauta may well index the power of the state to erase the part that people have played in the making of a collective future, its steely gaze also 
marks the beginning of a new process of material diagnostics. Here we find the failure of a material structure to properly enact itself as itself once again creating the possibility of an affective response out of which politics might once again be remade.

Hannah Knox is Lecturer in Digital Anthropology and Material Culture at University College London. She is editor of Objects and Materials: A Routledge Companion, and author of Roads: An Anthropology of Infrastructure and Expertise.

\section{Acknowledgements}

I would like to acknowledge the central role that Penny Harvey played in conducting this research project with me. Some of the ethnographic description in this essay is expanded and explored in more detail in our joint-authored monograph Roads: An Anthropology of Infrastructure and Expertise. The research upon which this essay is based was funded by the Economic and Social Research Council through the ESRC Centre for Research on Socio-Cultural Change and an ESRC Small Grant (Award Number: 000-22-1418).

\section{References}

Amin, Ash. 2013. "The Urban Condition: a Challenge to Social Science". Public Culture. 25 (2): 201-208

Anand, Nikhil. 2011. "Pressure: the Politechnics of Water Supply in Mumbai". Cultural Anthropology. 26 (4): 542-564.

Aretxaga, Begoña. 2003. "Maddening states". Annual Review of Anthropology. 32: 393410.

Ash Amin. 2014. "Lively Infrastructure". Theory, Culture \& Society. 31 (7-8): 137-161.

Bennett, Jane. 2010. Vibrant Matter: a Political Ecology of Things. Durham: Duke University Press.

Barad, Karen Michelle. 2007. Meeting the Universe Halfway: Quantum Physics and the Entanglement of Matter and Meaning. Durham, N.C.: Duke

Barry, Andrew. 2013. Material Politics: Disputes Along the Pipeline. Chichester: WileyBlackwell

Bessire, Lucas and Bond, David 2014. Ontological Anthropology and the Deferral of Critique. American Ethnologist 41: 440-456. doi:10.1111/amet.12083

Braun, Bruce, and Sarah Whatmore 2011. Political Matter : Technoscience, Democracy, and Public Life, Minneapolis, Minn.: University of Minnesota Press ; Bristol : University Press 
Coole, Diana H., and Samantha Frost. 2010. New Materialisms: Ontology, Agency, and Politics. Durham [NC]: Duke University Press.

De La Cadena, Marisol. 2010. "Indigenous Cosmopolitics in the Andes: Conceptual Reflections beyond "Politics"". Cultural Anthropology. 25 (2): 334-370.

Dalakoglou, Dimitris, and Penelope Harvey. 2015. Roads and Anthropology:

Ethnography, Infrastructures, (im)mobility. London: Routledge

Douglas, Mary. 1966. Purity and Danger; an Analysis of Concepts of Pollution and Taboo. New York: Praeger.

Fortun, Kim. 2013. "From Latour to Late Industrialism". HAU: Journal of Ethnographic Theory. 4 (1): 309-329.

Gandy, Matthew. 2008. Landscapes of Disaster: Water, Modernity, and Urban Fragmentation in Mumbai. Environment and Planning A 40:108-130.

Graeber, David. 2013. "It is Value that Brings Universes into Being". HAU: Journal of Ethnographic Theory. 3 (2): 219-243.

Gregg, Melissa, and Gregory J. Seigworth. 2010. The Affect Theory Reader. Durham, NC: Duke University Press.

Guldi, Jo. 2012. Roads to Power: Britain Invents the Infrastructure State. Cambridge, Mass: Harvard University Press

Habermas, Jurgen. 1989. The Structural Transformation of the Public Sphere: An Inquiry into a Category of Bourgeois Society, [Cambridge]: Polity 1989

Haraway, Donna J. 1991. Simians, Cyborgs, and Women: the Reinvention of Nature. New York: Routledge.

Harvey, Penelope, and Hannah Knox. 2012. "The Enchantments of Infrastructure". Mobilities. 7 (4).

Harvey, Penelope, and Hannah Knox. 2015. Roads: an Anthropology of Infrastructure and Expertise. Ithaca: Cornell University Press

Henare, Amiria J. M., Martin Holbraad, and Sari Wastell. 2007. Thinking through Things Theorising Artefacts Ethnographically. London: Routledge

Hetherington, Kregg. 2014. "Waiting for the Surveyor: Development Promises and the Temporality of Infrastructure". Journal of Latin American and Caribbean Anthropology. 19 (2): 195-211

Holbraad, Martin and Pedersen, Morten Axel. 2014. "The Politics of Ontology." Fieldsights - Theorizing the Contemporary, Cultural Anthropology Online http://www.culanth.org/fieldsights/461-the-politics-of-ontology 
Humphrey, Caroline. 2005. "Ideology in Infrastructure: Architecture and Soviet Imagination". The Journal of the Royal Anthropological Institute. 11 (1): 39-58.

Larkin, Brian. 2013. "The Politics and Poetics of Infrastructure". Annual Review of Anthropology. 42: 327-343

Latour, Bruno. 2005. Reassembling the Social: An Introduction to Actor-NetworkTheory. Oxford: Oxford University Press.

Latour, Bruno 1992. Where are the Missing Masses? The Sociology of a Few Mundane Artefacts. In Shaping Technology-Building Society. Studies in Sociotechnical Change, Wiebe Bijker and John Law (editors), MIT Press, Cambridge Mass. pp. 225-259

Law, John. 2015. "What's Wrong With a One-World World?" Distinktion: Scandinavian Journal of Social Theory. 16(1): 126-139.

Law, John and Vicky Singleton. 2014. "ANT, Multiplicity and Policy". Critical Policy Studies, 8(4): 379-396.

Marres, Noortje. 2008. 'The Making of Climate Publics: Eco-Homes as Material Devices of Publicity', Scandinavian Journal of Social Theory, 16: 27-46

Marres, Noortje. 2011. 'The Costs of Public Involvement : Everyday Devices of Carbon Accounting and the Materialization of Participation', Economy and Society, 40(4): 510533

Marres, Noortje, and Javier Lezaun 2011. 'Materials and Devices of the Public : An Introduction', Economy and Society, 40(4): 489-509

Martin, Keir. 2014. "Afterword Knot-Work Not Networks, or Anti-Anti-Antifetishism and the ANTipolitics machine". HAU: Journal of Ethnographic Theory. 4 (3): 99-115.

Mitchell, Timothy. 2011. Carbon Democracy: Political Power in the Age of Oil. London: Verso.

Mitchell, Timothy. 2006. 'Society Economy and the State Effect' in Sharma, Aradhana, and Akhil Gupta.(Eds). The Anthropology of the State: a Reader. Malden, MA:

Blackwell Pub.

Mol, Annemarie. 2002. The body multiple: ontology in medical practice. Durham: Duke University Press.

Navaro-Yashin, Yael. 2003. "'Life is Dead Here': Sensing the Political in 'No Man's Land'". Anthropological Theory. 3 (1): 107-125.

Nye, David E. 1994. American Technological Sublime. Cambridge, Mass: MIT Press.

Reeves, Madeleine. 2011, "Fixing the Border: on the Affective Life of the State in Southern Kyrgyzstan" Environment and Planning D: Society and Space 29(5) 905 - 923 
Robbins, Bruce. 2002. "The Sweatshop Sublime". PMLA. 117(1): 84-97.

Sharma, Aradhana and Akhil Gupta. 2006. The Anthropology of the State : A Reader. Oxford: Blackwell.

Shapin, Steven, Simon Schaffer. 1985. Leviathan and the Air-Pump: Hobbes, Boyle, and the Experimental Life. Princeton: Princeton University Press.

Star, Susan Leigh, and Karen Ruhleder. 1996. "Steps Toward an Ecology of Infrastructure: Design and Access for Large Information Spaces". Information Systems Research. 7(1): 111-134.

Stengers, Isabelle. 2010. Cosmopolitics I : I. The Science Wars, Ii. The Invention of Mechanics, Iii. Thermodynamics. Minneapolis, MN: University of Minnesota Press.

Stengers, Isabelle. 2011. "Including Nonhumans in Political Theory: Opening Pandora's Box?" In Political Matter : Technoscience, Democracy, and Public Life, Bruce Braun and Sarah Whatmore, eds., 3-33. Minneapolis, MN: University of Minnesota Press

Stoler, Andrew. 2004 “Affective states". In A Companion to the Anthropology of Politics ed. David Nugent, 4-20. Oxford: Blackwell.

Taussig, Michael. 1997. The Magic of the State, London: Routledge.

Turner, Terence. 2009. "The crisis of late structuralism: Perspectivism and animism: Rethinking culture, nature, spirit and bodiliness." Tipiti 7 (1): 3-40.

von Schnitzler, Antina. 2013. "Traveling Technologies: Infrastructure, Ethical Regimes, and the Materiality of Politics in South Africa." Cultural Anthropology 28, no. 4 (2013): $670-693$.

Viveiros de Castro, Eduardo. 1998. "Cosmological Deixes and Amerindian Perspectivism”. Journal of the Royal Anthropological Institute, 4(3): 469-488

Whatmore, Sarah J. and Catharina Landstrom. 2011. 'Flood Apprentices : An Exercise in Making Things Public', Economy and Society London-, 40(4): 582-610

\footnotetext{
${ }^{\mathrm{i}}$ Science and Technology Studies and in particular those working under the rubric of Actor Network Theory have of course been centrally concerned with the role of material relations in understanding social life for many years, but it is only relatively recently that
} 
political theorists have begun to apply these kinds of approaches to the study of political phenomena like the State. As Latour (1993) himself pointed out in We Have Never Been Modern, historians of science Shapin and Schaeffer, in their seminal study Leviathan and the Air Pump (Shapin and Schaffer 1985), provide a stunning account of the political origins of contemporary science, but they stop short of addressing the parallel question of the material and experimental conditions which led to the formation of the concept of the state.

ii Transitional Council of the Regional Administration of Loreto 